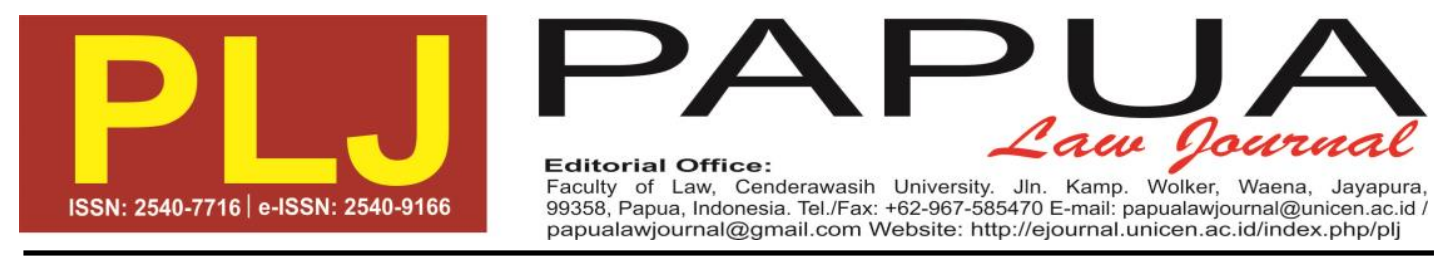

\title{
Penerapan Keadilan Restoratif (Restorative Justice) Dalam Penyelesaian Delik Adat
}

\author{
Budiyanto \\ Fakultas Hukum Universitas Cenderawasih \\ Jl. Kamp. Wolker, Waena, Jayapura, 99358, Papua, Indonesia \\ Tel./Fax.: +62-967-585470 E-mail: zeebudie@yahoo.com
}

\begin{abstract}
Abstrak: Penyelesaian suatu tindak pidana melalui peradilan formal (Pengadilan Negeri) umumnya masih dirasakan kurang memberikan rasa keadilan bagi korban. Bahkan seringkali masih menyimpan ketidakpuasan (dendam) dari korban (keluarga korban) atas hukuman atau sanksi pidana yang telah dijatuhkan kepada pelaku oleh pengadilan. Keadilan restoratif merupakan suatu solusi yang diharapkan dapat diterapkan dalam menyelesaikan delik adat, yang umumnya penyelesaiannya digagas oleh pelaku untuk menyelesaikan kasusnya secara damai bersama korban (keluarganya). Metode peneltian yang digunakan berupa penelitian hukum empiris (socio legal research). Hasil penelitian menunjukan bahwa penyelesaian delik adat di Papua pada dasarnya dilakukan dengan menerapkan konsep keadilan restoratif, yaitu ide penyelesaiannya dilakukan oleh pelaku kepada korban atau keluarga korban. Apabila tidak berhasil, akan diselesaikan melalui keluarga pelaku dan keluarga korban, atau melalui kepala suku/Ondoafi, atau melalui peradilan adat. Konsep keadilan restoratif ini diterapkan dalam penyelesaian delik adat semata-mata sebagai upaya untuk memulihkan penderitaan yang dialami korban dan untuk memperbaiki keseimbangan kosmis yang terganggu dalam masyarakat.
\end{abstract}

Kata Kunci: Keadilan Restoratif; Delik Adat

Abstract: The of an offense through the formal justice (District Court) in general, still less to give a sense of justice for the victims. Moreover, often still save dissatisfaction (revenge) of the victim (victims' families) on penalties or criminal sanctions that have been imposed on the perpetrators by the courts. Restorative justice is expected to be one option that can be applied in resolving the customs offense, which is generally initiated by the offender settlement to resolve the case amicably with the victims (families). This study was an empirical research (socio legal research). The results of the research indicated that the completion of indigenous offenses in Papua actually using by restorative justice concept, namely the idea of settlement by the perpetrator to the victim or the victim's family. If it does not meet an agreement, will be resolved through the perpetrator's family and the families of the victims, or through chieftain Ondoafi, or through customary justice. The concept of restorative justice is applied in the completion of customs offenses solely as an attempt to relieve the suffering endured by the victims and to repair the cosmic balance which disturbed in society.

Keywords: Restorative Justice; Indigenous offense 


\section{PENDAHULUAN}

Indonesia terdiri atas beraneka ragam suku, bahasa dan adat istiadat. Keberadaan suku-suku, tidak saja harus diterima dan hormati sebagai kenyataan sosiologis dan sejarah, tetapi harus pula dipelihara dan dijaga untuk mewujudkan satu tujuan dan satu cita-cita bernegara sebagaimana tertuang dalam Pancasila dan Undang-Undang Dasar Negara Republik Indonesia Tahun 1945. ${ }^{1}$ Hal ini penting bagi terciptanya suasana kehidupan masyarakat yang penuh toleransi, tenggang rasa, dan harmonis.

Kenyataannya, dalam kehidupan bermasyarakat, tidak menutup kemungkinan terjadi ketidakharmonisan yang disebabkan oleh pelanggaran terhadap norma yang ada. Pelanggaran tersebut dipandang dapat menimbulkan kegoncangan dalam masyarakat, karena dianggap telah mengganggu keseimbangan kosmis. Oleh karena itu untuk mengembalikan keadaan seperti semula atas pelanggaran yang terjadi, maka si

1 Undang-Undang Rencana Pembangunan Jangka Panjang Nasional Tahun 2005-2025 (UU RI No. 17 Th. 2007). (2007). Jakarta: Sinar Grafika, hal. 7 pelanggar harus diberikan sanksi adat. ${ }^{2}$ Hal ini berarti keseimbangan yang telah terganggu tersebut baru dapat kembali normal bila ada penyelesaian yang ditempuh oleh pelaku dan korban, sehingga kedamaian dalam masyarakat dapat tercipta kembali.

Penyelesaian delik adat pada umumnya dapat diselesaikan melalui tahapan musyawarah antara korban dan pelaku, upaya perdamaian, upaya mediasi, dan penyelesaian melalui lembaga adat (peradilan adat). Apabila dalam penyelesaian delik adat ternyata ada salah satu pihak yang menolak, maka penyelesaian akhirnya adalah melalui peradilan formal (Pengadilan Negeri).

Dalam pelaksanaan sistem peradilan pidana keterlibatan korban masih belum nyata kelihatan dalam menentukan dan mencari keadilan yang diinginkan dan diidam-idamkan. Penyelesaian melalui konsep keadilan restoratif yang sudah dikenal oleh masyarakat sejak lama seharusnya dapat diwujudkan dalam mencari keadilan di setiap tahap peradilan pidana, yaitu dengan melibatkan seluruh pihak untuk

2 I Made Widnyana. (1993). Kapita Selekta Hukum Pidana Adat. Bandung: PT. Eresco, hal. 3 
dapat secara terbuka didengar dan menentukan konsep penyelesaian dan pemberian sanksi yang seadil-adilnya bagi kepentingan korban atau keluarganya.

Sungguhpun disadari bahwa penyelesaian melalui peradilan formal (Pengadilan Negeri) umumnya masih dirasakan kurang memberikan rasa keadilan bagi korban, dan seringkali masih menyimpan ketidakpuasan (dendam) dari korban (keluarga korban) atas hukuman atau sanksi pidana yang telah dijatuhkan kepada pelaku oleh pengadilan. Oleh karena itu, penerapan keadilan restoratif dalam penyelesaian delik adat secara musyawarah mufakat dalam bentuk perdamaian adat masih menjadi primadona masyarakat dalam menyelesaikan delik adat yang terjadi.

Bentuk penyelesaian antara pelaku dan korban secara kekeluargaan ataupun melalui lembaga peradilan adat ini merupakan bentuk penyelesaian yang bertujuan mencari keadilan yang hakiki, yang dalam kenyataannya mirip dengan konsep keadilan restotratif (restorative justice). Konsep keadilan restoratif digagas oleh pelaku dan korban untuk menyelesaikan persoalan secara damai dengan mengutamakan prinsip musyawarah dan mufakat.
Konsep keadilan restoratif ini sesunggguhnya sudah lama diterapkan oleh masyarakat hukum adat di berbagai wilayah di Indonesia dalam rangka penyelesaian delik adat yang terjadi atau dalam menyelesaikan kasus tindak pidana ringan. Namun baru akhir-akhir ini konsep keadilan restoratif muncul kembali di saat kepercayaan masyarakat terhadap peradilan formal mulai luntur, putusan pengadilan tidak lagi dapat memberikan rasa keadilan pada masyarakat, penyelesaian yang tidak tuntas dan bahkan seringkali menimbulkan masalah baru dalam masyarakat akibat putusan yang dianggap tidak sesuai dengan harapan masyarakat luas. Melalui penerapan keadilan restoratif dalam penyelesaian delik adat, maka kepentingan korban yang selama ini oleh peradilan formal diabaikan, menjadi lebih diperhatikan dalam pertemuan yang digelar oleh kedua belah pihakm, dan dalam suasana kekeluargaan. Perdamaian yang ditempuh oleh para pihak semata-mata bertujuan untuk mencari keadilan dan memulihkan keadaan kembali seperti sediakala.

Berdasarkan kondisi tersebut maka fokus dalam pembahasan ini lebih ditekankan pada masalah penerapan 
keadilan restoratif dalam penyelesaian delik adat, dan bentuk-bentuk penyelesaian delik adat yang ditempuh oleh para pihak dalam upaya mencari keadilan baik melalui peradilan adat atau peradilan formal.

\section{METODE}

Penelitian ini dikategorikan dalam jenis penelitian hukum sosiologis/ empiris (socio legal research), yaitu jenis penelitian yang berorientasi pada aspek hukum dan aspek non hukum yakni mengkaji dan menganalisis bekerjanya hukum dalam masyarakat. Penelitian ini menitikberatkan pada perilaku individu atau masyarakat dalam kaitannya dengan hukum. ${ }^{3}$ Sumber data dalam penelitian penelitian ini meliputi data primer yang yang berasal dari pelaku, korban, keluarga pelaku dan keluarga korban, aparat kepolisian, dan pemangku adat. Data sekunder, diperoleh melalui sumber bahan hukum primer yaitu peraturan perundang-undangan, dan putusan pengadilan. Bahan hukum sekunder yang berasal dari karya ilmiah dan media internet. Adapun bahan hukum tertier yang berasail dari kamus dan

\footnotetext{
${ }^{3}$ Peter Mahmud Marzuki. (2008). Penelitian Hukum. Jakarta: Kencana Prenada Media Group, hal. 87
}

ensiklopedia. Keseluruhan data tersebut selanjutnya diinventarisir dan diolah, kemudian dianalisis dengan teknik analisis kualitatif sesuai dengan objek kajian yang diteliti guna mendapatkan gambaran yang jelas terhadap realitas yang terjadi di masyarakat.

\section{PEMBAHASAN}

Konsep Restorative Justice (Keadilan Restoratif)

Pengertian tentang Restorative Justice telah banyak dirumuskan oleh para ahli. Menurut Sarre, ${ }^{4}$ bahwa:

$$
\begin{aligned}
& \text { "...restorative justice is } \\
& \text { concerned with rebuilding } \\
& \text { relationships after an offence, } \\
& \text { rather driving a wedge between } \\
& \text { offenders and, their communities, } \\
& \text { which is the hallmark of modern } \\
& \text { criminal justice systems". }
\end{aligned}
$$

(Keadilan restoratif berkaitan dengan bagaimana membangun kembali hubungan setelah terjadi suatu tindak pidana, bukannya membangun tembok pemisah antara para pelaku tindak pidana dengan masyarakat mereka, yang merupakan hallmark (tanda/ karakteristik) dari sistem-sistem peradilan pidana modern).

Menurut Howard Zehr, sebagaimana dikutip Bambang Waluyo, ${ }^{5}$ bahwa:

\footnotetext{
4 Rufinus Hotmaulana Hutauruk. (2013). Penanggulangan Kejahatan Korporasi Melalui Pendekatan Restoratif Suatu Terobosan Hukum. Jakarta: Sinar Grafika, hal.108
} 
"Restorative justice" is a process to involve, to the extent possible, those who have a stake in a specific offense and to collectively identify and address harms, needs, and obligation in order to heal and put things as right as possible. (Keadilan restoratif adalah proses untuk melibatkan dengan menggunakan segala kemungkinan, seluruh pihak terkait dan pelanggaran tertentu dan untuk mengidentifikasi serta menjelaskan ancaman, kebutuhan dan kewajiban dalam rangka menyembuhkan serta menempatkan hal tersebut sedapat mungkin sesuai dengan tempatnya).

Selanjutnya dalam Pasal 1 angka 6 Undang-undang Nomor 11 Tahun 2012 tentang Sistem Peradilan Pidana Anak bahwa keadilan restoratif adalah "penyelesaian perkara tindak pidana dengan melibatkan pelaku, korban, keluarga pelaku/korban, dan pihak lain yang terkait untuk bersama-sama mencari penyelesaian yang adil dengan menekankan pemulihan kembali pada keadaan semula, dan bukan pembalasan". 6

Pengertian menurut pendapat ahli yang lain bahwa Restorative justice

5 Bambang Waluyo. (2015). Relevansi Doktrin Restorative Justice Dalam Sistem Pemidanaan di Indonesia (The Relevance of the Doctrine on Restorative Justice in the Indonesian Sentencing System), Hassanuddin Law Review, Volume 1, Issu 2, hal. 213

${ }^{6}$ Ibid. adalah suatu penyelesaian secara adil yang melibatkan pelaku, korban, keluarga mereka dan pihak lain yang terkait dalam suatu tindak pidana, secara bersama-sama mencari penyelesaian terhadap tindak pidana tersebut dan implikasinya, dengan menekankan pemulihan dan bukan pembalasan. ${ }^{7}$

Berdasarkan pengertian yang dikemukan tentang restorative justice tersebut, maka menurut Edwin Syah Putra, bahwa Restorative Justice mengandung prinsip-prinsip dasar yang meliputi:

1. Mengupayakan perdamaian di luar pengadilan oleh pelaku tindak pidana (keluarganya) terhadap korban tindak pidana (keluarganya);

2. Memberikan kesempatan kepada pelaku tindak pidana (keluarganya) untuk bertanggung jawab menebus kesalahannya dengan cara mengganti kerugian akibat tindak pidana yang dilakukannya.

3. Menyelesaikan permasalahan hukum pidana yang terjadi diantara pelaku tindak pidana dan korban tindak pidana tersebut apabila tercapai persetujuan dan kesepakatan diantara para pihak. ${ }^{8}$

${ }^{7}$ Munawara, M. Syukri Akkub, Musakkir. Pendekatan Restorative Justice Dalam Penyelesaian Tindak Pidana Yang Dilakukan Oleh Anak Di Kota Makassar. Makassar: Fakultas Hukum Universitas Hasanuddin. Makassar, hal. 4.

8 Edwin Syah Putra. Restorative Justice (Pengertian, Prinsip dan Keberlakuannya Dalam Sistem Hukum Pidana Indonesia). Dikutip pada laman web: http://edwinnotaris. 
Kuat Puji Prayitno ${ }^{9}$ membagi prinsip dasar yang menonjol dari restorative justice terkait hubungan antara kejahatan, pelaku, korban, masyarakat dan negara, yaitu:

1. Kejahatan ditempatkan sebagai gejala yang menjadi bagian tindakan sosial dan bukan sekedar pelanggaran hukum pidana;

2. Restorative Justice adalah teori peradilan pidana yang fokusnya pada pandang-an yang melihat bahwa kejahatan adalah seba-gai tindakan oleh pelaku terhadap orang lain atau masyarakat daripada terhadap negara. Jadi lebih menekankan bagaimana hubungan/ tanggungjawab pelaku (individu) dalam menyelesaikan masalahnya dengan korban dan atau masyarakat;

3. Kejahatan dipandang sebagai tindakan yang merugikan orang dan meru-sak hubungan sosial. "Ini jelas berbeda dengan hukum pidana yang telah menarik kejahatan sebagai masalah negara, hanya negara yang berhak menghukum"; keempat, munculnya ide restorative justice sebagai kritik atas penerap-an sistem peradilan pidana dengan pemenjara-an yang dianggap

blogspot.com/2013/09/restorative-justicepengertian-prinsip.html. Tanggal 20 September 2013. Pukul. 17.50.

9 Kuat Puji Prayitno. (2012). Restorative Justice Untuk Peradilan Di Indonesia (Perspektif Yuridis Filosofis Dalam Penegakan Hukum In Concreto). Jurnal Dinamika Hukum Vol.12 No.3 September 2012. Fakultas Hukum Universitas Jenderal Soedirman, hal. 411 tidak efektif menyelesaikan konflik sosial.

Selanjutya Helen Cowie dan Dawn Jeniffer sebagaimana dikutip Hadi Supeno telah mengidentifikasikan aspek-aspek utama keadilan restoratif sebagai berikut:

1. Perbaikan, yaitu bukanlah tentang memperoleh kemenangan atau menerima kekalahan, tudingan, atau pembalasan dendam, tetapi tentang keadilan.

2. Pemulihan hubungan, yaitu bukan bersifat hukuman para pelaku kriminal memikul tanggung jawab atas kekeliruan dan memperbaikinya dengan sejumlah cara, tetapi melalui proses komunikasi yang terbuka dan langsung, antara korban dan pelaku kriminal, yang berpotensi mengubah cara berhubungan satu sama lain.

3. Reintegrasi, pada tingkatnya yang terluas, memberikan arena tempat anak dan orangtua dapat memperoleh proses yang adil. Maksudnya agar mereka belajar tentang konsekuensi kekerasan dan kriminalitas serta memahami dampak perilaku mereka terhadap orang lain. ${ }^{10}$

Berkaitan dengan konsep restorative justice, Muladi dalam Abintoro

\footnotetext{
${ }^{10}$ Hadi Supeno. (2010). Kriminalisasi Anak Tawaran Gagasan Radikal Peradilan Anak Tanpa Pemidanaan. Jakarta: PT. Gramedia Pustaka Utama, hal. 203
} 
Prakoso $^{11}$ merinci tentang ciri-ciri restorative justice sebagai berikut:

1. Kejahatan dirumuskan sebagai pelanggaran seseorang terhadap orang lain dan dipandang sebagai konflik;

2. Fokus perhatian pada pemecahan masalah pertanggungjawaban dan kewajiban untuk masa mendatang;

3. Sifat normatif dibangun atas dasar dialog dan negosiasi;

4. Restitusi sebagai sarana para pihak, rekonsiliasi dan restorasi merupakan tujuan utama;

5. Keadilan dirumuskan sebagai hubungan antar hak, dinilai atas dasar hasil;

6. Fokus perhatian terarah pada perbaikan luka sosial akibat kejahatan;

7. Masyarakat merupakan fasilitator di dalam proses restoratif;

8. Peran korban dan pelaku diakui, baik dalam penentuan masalah maupun penyelesaian hak-hak dan kebutuhan korban. Pelaku didorong untuk bertanggung jawab;

9. Pertanggungjawaban pelaku dirumuskan sebagai dampak pemahaman atas perbuatannya dan diarahkan untuk ikut memutuskan yang terbaik;

10. Tindak pidana dipahami dalam konteks menyeluruh, moral, sosial dan ekonomis;

11. Stigma dapat dihapus melalui restoratif.

Pengenalan Restorative Justice

(Keadilan Restoratif) di dalam sistem

11 Abintoro Prakoso. (2013). Pembaruan Sistem Peradilan Pidana Anak. Yogyakarta: Laksbang Grafika, hal. 163-164 hukum Indonesia masih bersifat parsial dan tidak komprehensif. Menurut DS. Dewi, penerapan Retorative Justice (keadilan restoratif) tampak dalam beberapa kebijakan, sebagai berikut: ${ }^{12}$

1. Surat Edaran Mahkamah Agung (SEMA) No. 6 Tahun 1959, menyebutkan bahwa persidangan anak harus dilakukan secara tertutup.

2. Surat Edaran Mahkamah Agung (SEMA) No. 6 Tahun 1987, tanggal 16 November 1987 tentang Tata Tertib Sidang Anak.

3. Surat Edaran Jaksa Agung RI SE002/j.a/4/1989

Penuntutan terhadap Anak

4. Surat Jaksa Agung Muda Tindak Pidana Umum B-532/E/11/1995, 9 Nov 1995 tentang Petunjuk Teknis Penuntutan Terhadap Anak

5. MOU 20/PRS-2/KEP/2005 DitBinRehSos Depsos RI dan DitPas DepKumHAM RI tentang pembinaan luar lembaga bagi anak yang berhadapan dengan hukum

6. Surat Edaran Ketua Mahkamah Agung RI MA/Kumdil/ 31/I/K/2005 tentang kewajiban setiap PN mengadakan ruang sidang khusus \& ruang tunggu khusus untuk anak yang akan disidangkan

7. Himbauan Ketua MARI untuk menghindari penahanan pada

12 Rocky Marbun. (2012). Membangun Restorative Justice Dan Penal Mediation Dalam Sistem Peradilan Pidana Di Indonesia. Dikutip pada halaman web: http://forumdunia hukumblogku.wordpress.com/2012/08/22/mem bangun-restorative-justice-dan penal-mediationdalam-sistem-peradilan-pidana-di-indonesia/. Tanggal 22 Augustus 2012. 
anak dan mengutamakan putusan tindakan daripada penjara, 16 Juli 2007

8. Peraturan KAPOLRI 10/2007, 6 Juli 2007 tentang Unit Pelayanan Perempuan dan Anak (PPA) dan 3/2008 tentang pembentukan RPK dan tata cara pemeriksaan saksi\&/korban TP

9. TR/1124/XI/2006 dari Kabareskrim POLRI, 16 Nov 2006 dan TR/395/VI/2008 9 Juni 2008, tentang pelaksaan diversi dan restorative justice dalam penanganan kasus anak pelaku dan pemenuhan kepentingan terbaik anak dalam kasus anak baik sebagai pelaku, korban atau saksi

10. Kesepakatan Bersama antara Departemen Sosial RI Nomor: 12/PRS-2/KPTS/2009,

Departemen Hukum Dan Hak Asasi Manusia RI Nomor: M.HH.04.HM.03.02 Th 2009, Departemen Pendidikan Nasional RI Nomor 11/XII/KB/2009, Departemen Agama RI Nomor: 06/XII/2009, dan Kepolisian Negara RI Nomor: B/43/ XII/2009 tentang Perlindungan dan Rehabilitasi Sosial Anak Yang Berhadapan dengan Hukum, tanggal 15 Desember 2009

11. Surat Keputusan Bersama Ketua Mahkamah Agung RI, Jaksa Agung RI, Kepala Kepolisian Negara RI, Menteri Hukum Dan HAM RI, Menteri Sosial RI, Menteri Pemberdayaan Perempuan Dan Perlindungan Anak RI, NO.166/KMA/SKB/XII/2009,

NO.148 A/A/JA/12/2009, NO. B/45/XII/2009, NO. M.HH-08 HM.03.02 Tahun 2009, NO. 10/PRS-2/KPTS/2009, NO.
02/Men.PP dan PA/XII/2009 tanggal 22 Desember 2009 tentang Penanganan Anak Yang Berhadapan Dengan Hukum.”

\section{Definisi Delik Adat}

Istilah delik adat sering pula disebut dengan Hukum Pidana Adat. Istilah ini menurut beberapa literatur berasal dari "Adat Delicten Recht" yang berarti hukum pelanggaran adat. $^{13}$ Menurut Ter Haar, diartikan sebagai setiap gangguan terhadap benda materiil maupun inmateriil kepunyaan orang perorangan atau kelompok sosial. Dalam masyarakat adat, dimana terhadap gangguan-gangguan tersebut menimbulkan reaksi negatif yang menuntut pemulihan kembali dari keseimbangan kosmis yang terganggu tersebut. ${ }^{14}$

Menurut para pakar, pengertian delik adat (hukum pidana adat) sebagai berikut:

1. Nyoman Serikat Putra Jaya, bahwa untuk dapat disebut tindak pidana adat, perbuatan itu harus mengakibatkan kegoncangan dalam neraca keseimbangan masyarakat. Kegoncangan itu tidak hanya terdapat apabila peraturan hukum dalam suatu

13 Hilman Hadikusuma. (1989). Hukum Pidana Adat. Bandung: Alumni, hal.7

${ }^{14}$ Soerjono Soekanto dan Mustafa Abdullah. 1982. Pengantar Hukum Adat Indonesia. Jakarta: PT RajaGrafindo Persada, hal. 81 
masyarakat dilanggar, tetapi juga apabila norma-norma kesusilaan, keagamaan, dan sopan santun dalam masyarakat dilanggar. ${ }^{15}$

2. Cornellis Van Vollenhoven, pengertian "delik adat" adalah" perbuatan yang tidak boleh dilakukan", walaupun pada kenyataannya peristiwa atau perbuatan itu hanya sumbang (kesalahan) kecil saja. ${ }^{16}$

3. I Made Widnyana menyatakan, delik adat adalah hukum yang hidup (living law) yang diikuti dan ditaati oleh masyarakat adat secara terus menerus dari suatu generasi ke generasi berikutnya. Delik adat sebagai hukum yang hidup adalah semua perbuatan atau kejadian yang bertentangan dengan kepatuhan, kerukunan, ketertiban, keamanan rasa keadilan dan kesadaran masyarakat yang bersangkutan baik hal itu sebagai akibat dari perbuatan yang dilakukan oleh seseorang, sekelompok orang maupun perbuatan yang dilakukan oleh pengurus adat sendiri, perbuatan mana dipandang dapat menimbulkan kegoncangan karena mengganggu keseimbangan kosmos serta menimbulkan reaksi dari masyarakat berupa sanksi adat, melalui pengurus adatnya. ${ }^{17}$ Pengertian ini mengandung tiga hal pokok yaitu: Pertama, rangkaian peraturan tata tertib yang dibuat, diikuti dan di taati

\footnotetext{
15 Nyoman Serikat Putra Jaya. (2005). Relevansi Hukum Pidana Adat Dalam Pembaharuan Hukum Pidana Nasional. Bandung: PT Citra Aditya Bakti, hal. 33

16 Tolib Setiady. (2008). Intisari Hukum Adat Indonesia (Dalam Kajian Kepustakaan). Bandung: Alfabeta, hal. 345

17 I Made Widnyana. (1993). Op. Cit. hal. 346
}

masyarakat adat bersangkutan. Kedua, pelanggaran terhadap peraturan tata tertib tersebut dapat menimbulkan kegoncangan karena dianggap mengganggu keseimbangan kosmis. Perbuatan melanggar peraturan tata tertib ini dapat disebut sebagai delik adat. Ketiga, pelaku yang melakukan pelanggaran tersebut dapat dikenai sanksi oleh masyarakat yang bersangkutan.

Berdasarkan pandangan tersebut, maka menurut penulis bahwa delik adat pada dasarnya adalah setiap perbuatan yang bertentangan kehendak masyarakat, merupakan perbuatan yang dilarang, yang dilakukan oleh seseorang atau sekelompok orang sehingga menimbulkan gangguan atau kegoncangan dalam masyarakat, dan atas kegoncangan tersebut menimbulkan reaksi dari masyarakat yang berupa sanksi adat.

\section{Sifat Delik Adat (Hukum Pidana}

Adat)

I Made Widnyana ${ }^{18}$ menyatakan bahwa hukum pidana adat itu memiliki sifat-sifat sebagai berikut:

1. Menyeluruh dan menyatukan. Karena di jiwai oleh sifat kosmis, yang manasatu sama lain saling berhubungan. Hukum pidana adat tidak membedakan pelanggaran yang bersifat pidana dan

\footnotetext{
${ }^{18}$ Ibid.
} 
pelanggaran yang bersifat perdata.

2. Ketentuan yang terbuka. Hal ini didasarkan atas ketidak mampuan meramal apa yang akan terjadi sehingga ketentuannya selalu terbuka untuk segala peristiwa atau perbuatan yang mungkin terjadi.

3. Membeda-bedakan permasalahan. Apabila terjadi peristiwa pelanggaran, maka yang dilihat bukan semata-mata perbuatan dan akibatnya tetapi dilihat apa yang menjadi latar belakang dan siapa pelakunya. Dengan alam pikiran demikian, maka dalam mencari penyelesaian dalam suatu peristiwa menjadi berbeda.

4. Peradilan dengan permintaan. Menyelesaikan pelanggaran adat sebagian besar berdasarkan adanya permintaan atau pengaduan, adanya tuntutan atau gugatan dari pihak yang dirugikan atau diperlakukan tidak adil.

5. Tindakan reaksi atau koreksi. Tindakan reaksi atau koreksi ini tidak hanya dapat dikenakan pada si pelaku pelanggaran saja tetapi dapat juga dikenakan pada kerabatnya/ keluarganya bahkan mungkin juga dibebankan pada masyarakat yang bersangkutan untuk mengembalikan keseimbangan yang terganggu.

Berdasarkan sifat delik adat sebagaimana dikemukan oleh I Made Widnyana tersebut, maka menurut penulis bahwa sifat delik adat tersebut merupakan manifestasi yang utuh dan murni dari masyarakat hukum adat yang berpegang teguh atas prinsip-prinsip dasar yang harus dijaga dan dilestarikan keutuhannya, sehingga apabila terjadi pelanggaran atas apa yag telah disepakatai bersama tersebut, maka akan menimbulkan tindakan reaksi dari masyarakat yang berupa sanksi adat guna untuk mengembalikan atau memulihkan keadaan akibat keseimbangan yang telah terganggu.

\section{Penerapan Keadilan Restoratif}

Konflik atau perang merupakan bagian tidak terpisahkan dari budaya dan sejarah hidup umat manusia. Konflik senantiasa hadir sebagai ungkapan ekspresi emosional terhadap fenomena sosial budaya yang terjadi, hidup dan berkembang di tengah masyarakat. ${ }^{19}$ Pada dasarnya konflik merupakan suatu keadaan yang timbul sebagai akibat dari terganggunya hubungan antara dua pihak. Masingmasing pihak merasa benar dan tidak mengakui kelemahannya, dan berupaya untuk mempertahankan kehendaknya. Konflik dapat dipandang dari aspek positif dan negatif. Dari aspek positif

19 Ismael Roby Silak. (2011). Konflik Perang dan Perdamaian Orang Yali di Angguruk. Makassar: Pustaka Refleksi, hal. 1 
karena adanya konflik, maka ada upaya untuk mempersatukan adanya perbedaan yang terjadi melalui mekanisme yang disepakati. Dari aspek negatifnya bahwa konflik menyebabkan hubungan yang awalnya baik dan harmonis, maka menjadi retak dan tidak harmonis lagi, dan hilang suasana keakrabannya. ${ }^{20}$

Pada umumnya masyarakat berpandangan bahwa sengketa (konflik) hanya bisa diselesaikan melalui jalur Pengadilan, bahkan sebagian besar kalangan profesional hukum pun berpandangan yang sama. Sampai saat ini banyak dari kalangan mereka hanya terpaku memilih jalur litigasi dan melupakan serta mengabaikan cara-cara penyelesaian sengketa melalui jalur non-litigasi misalnya melalui Alternatif Penyelesaian Sengketa (ADR). Sebagaimana dikutib dalam bukunya I Made Widnyana, bahwa Dispute Resolution yang biasa disebut "Alternative Dispute Resolution" adalah serangkaian proses yang bertujuan untuk menyelesaikan sengketa antara pihak-pihak. ${ }^{21}$

Sengketa atau konflik merupakan sebuah fenomena sosial di dalam

\footnotetext{
${ }^{20}$ Ibid., hal. 6

${ }^{21}$ Ibid., hal. 11
}

sebuah pergaulan di masyarakat. ${ }^{22}$ Menurut Randall Collins, konflik adalah proses sentral dalam kehidupan sosial. ${ }^{23}$ Jadi, dalam kehidupan sosial/ bermasyarakat tentunya pasti akan selalu timbul konflik. Sebetulnya, konflik dapat berimplikasi positif, yakni, dapat membantu individu-individu/kelompokkelompok yang berkonflik tersebut menjadi lebih erat hubungannya. Hal tersebut dapat menciptakan kohesi sosial yang dapat mendorong terbentuknya stabilitas nasional. Akan tetapi, dalam realitasnya, sisi positif tersebut jarang terjadi, justru sisi negatif dari konflik, seperti terjadinya disintegrasi yang sering muncul. Di dalam masyarakat tradisional (adat), konflik yang timbul biasanya diselesaikan dengan cara-cara perdamaian. Hal ini dilakukan untuk mencegah terjadinya permusuhan, pertikaian, perpecahan (disintegrasi), dan sebagainya. Dalam menyelesaikan suatu konflik masingmasing individu/kelompok memiliki caranya masing-masing. Menurut Nader

22 Hendra Nurtjahjo dan Fokky Fuad. (2010). Legal Standing Kesatuan Masyarakat Hukum Adat Dalam Berperkara di Mahkamah Konstitusi. Jakarta: Salemba Humanika, hal. 4446

${ }^{23}$ George Ritzer dan Douglas J. Goodman. (2003). Teori Sosiologi Modern. Jakarta: Kencana, hal. 16 
dan Todd, ada beberapa cara/tahapan yang biasa dilakukan seseorang dalam menyelesaikan konflik/sengketa yang dihadapinya, yaitu: ${ }^{24}$

1. Membiarkan saja (lumping it) Dalam tahapan ini, pihak yang merasa diperlakukan tidak adil/ dirugikan gagal dalam upaya menekan tuntutannya. Ia mengambil keputusan untuk mengabaikan saja masalah/isu yang menimbulkan tuntutannya dan ia meneruskan hubungan-hubungannya dengan pihak yang dirasakan merugikannya. Ini dilakukan karena berbagai kemungkinan, seperti kurangnya informasi mengenai bagaimana proses mengajukan keluhan itu ke peradilan, kurangnya akses ke lembaga peradilan atau sengaja tidak diproses ke peradilan karena diperkirakan bahwa kerugiannya lebih besar dari keuntungannya (baik materiil maupun kejiwaannya).

2. Mengelak (avoidance). Pada tahapan ini, pihak yang merasa dirugikan memilih untuk mengurangi hubungan-hubungan dengan pihak yang merugikannya atau untuk sama sekali menghentikan hubungan tersebut. Misalnya, dalam hubungan bisnis, hal semacam ini dapat terjadi. Dengan mengelak, maka isu yang menimbulkan keluhan dielakkan saja. Berbeda dengan pemecahan pertama, di mana hubunganhubungan berlangsung terus, isunya saja yang dianggap selesai, dalam bentuk kedua ini, pihak yang dirugikan mengelakkannya

${ }^{24}$ T.O Ihromi. (2001). Antropologi Hukum Sebuah Bunga Rampai. Jakarta: Yayasan Obor Indonesia, hal. 210-211 dan menghentikan hubunganhubungan untuk sebagian atau keseluruhan.

3. Paksaan (coersion). Tahapan selanjutnya, yaitu paksaan (coersion) di mana salah satu pihak memaksakan pemecahan kepada pihak lain. Ini bersifat unilateral. Tindakan yang bersifat memaksakan ini atau ancaman untuk menggunakan kekerasan, pada umumnya mengurangi kemungkinan penyelesaian secara damai.

4. Perundingan (negotiation). Pada tahapan perundingan, dua pihak yang berhadapan merupakan para pengambil keputusan. Pemecahan dari permasalahan yang mereka hadapi dilakukan oleh mereka berdua, mereka sepakat, tanpa adanya pihak ketiga yang mencampuri. Kedua pihak berupaya untuk saling meyakinkan, jadi mereka membuat aturan mereka sendiri dan tidak memecahkannya dengan bertitik tolak dari aturan-aturan yang ada.

5. Mediasi (mediation). Dalam cara ini, ada pihak ketiga yang membantiu kedua pihak yang berselisih pendapat untuk menemukan kesepakatan. Pihak ketiga ini dapat ditentukan oleh kedua belah pihak yang bersengketa atau ditunjukkan oleh yang berwenang untuk itu. Apakah mediator hasil pilihan kedua pihak atau karena ditunjuk oleh orang yang mempunyai kekuasaan, kedua pihak yang bersengketa harus setuju bahwa jasa-jasa dari seorang mediator akan digunakan dalam upaya mencari pemecahan. Dalam masyarakat-masyarakat kecil (paguyuban) bisa saja ada tokohtokoh yang berperan sebagai 
mediator, juga berperan sebagai arbitrator dan sebagai hakim.

6. Arbitrage. Kedua belah pihak yang bersengketa sepakat untuk meminta perantara pihak ketiga, arbitrator, dan sejak semula telah setuju bahwa mereka akan menerima keputusan dari arbitrator itu.

7. Peradilan (adjudication). Di sini, pihak ketiga mempunyai wewenang untuk mencampuri pemecahan masalah, lepas dari keinginan para pihak bersengketa. Pihak ketiga itu juga berhak membuat dan menegakkan keputusan itu artinya bahwa keputusan berupaya dilaksanakan.

Merujuk pada pendapat Nader dan Todd tersebut, dapat diketahui bahwa penyelesaian delik adat yang terjadi pada masyarakat hukum adat di Papua ditempuh dengan menggunakan konsep keadilan restoratif (restorative justice). Penerapan keadilan restoratif ini nampak ketika penyelesaian tersebut melibatkan pelaku dan korban sebagai pihak yang berkompeten dalam perkara tersebut. Para pihak berupaya untuk melakukan dialog dan melakukan pertemuan untuk menyelesaikan secara musyawarah dan mufakat sehingga tercapai kesepakatan.

Penyelesaian delik adat yang terjadi di masing-masing suku berbedabeda mekanisme dan cara yang dilakukan, tetapi pada umumnya memiliki tujuan yang sama yaitu untuk mengembalikan keadaan kosmis yang terganggu sehingga terciptanya kembali keharmonisan dan keserasian dalam kehidupan masyarakat. Adapun penerapan keadilan restoratif terlihat dalam mekanisme penyelesaian delik adat yang terjadi pada masyarakat hukum adat di Papua, yaitu:

1. Penyelesaian oleh para pihak yang bersengketa, yaitu pelaku dan korban sepakat untuk bertemu dan saling duduk bersama untuk bermusyawarah dan berupaya mencari penyelesaian yang dipandang adil dan sesuai dengan kebiasaan yang berlaku dalam masyarakat. Biasanya kedua belah pihak sama-sama menyadari kesalahan masing-masing dan sama-sama saling memaafkan sehingga bersepakat untuk berdamai dan tidak saling menuntut dan mendendam.

2. Penyelesaian musyawarah antar keluarga, yaitu penyelesaian yang ditempuh oleh para pihak yang tidak mencapai kesepakatan dalam mencari solusi, kemudian diselesaikan melalui para keluarga pelaku dan korban. Para pihak bertemu di tempat rumah korban atau pelaku atau di rumah keluarga lain sesuai dengan kesepakatan bersama. Dalam pertemuan tersebut para pihak dan para anggota keluarga berkumpul dan bermusyawarah untuk mencari upaya penyelesaian yang seadil-adilnya bagi kedua belah pihak. Umumnya penyelesaian di tingkat keluarga ini sangat efektif pada saat keluarga masih ada 
ikatan kekerabatan sehingga kesepakatan akan lebih mudah dicapai dibandingkan dengan tidak ada ikatan kekerabatan.

3. Penyelesaian melalui mediasi, upaya penyelesaian ini dilakukan apabila penyelesaian yang telah ditempuh di tingkat antar keluarga tidak mencapai kesepakatan dan perdamaian. Penyelesaian melalui mediasi ini dilakukan oleh para pihak yang bersengketa untuk mencari dan menunjuk seorang mediator yang biasanya adalah dari tokoh masyarakat (tomas), tokoh adat (todat), tokoh gereja (toga), atau dari aparat kepolisian.

4. Penyelesaian melalui kepala suku, upaya penyelesaian ini dilakukan apabila cara penyelesaian antar para pihak, keluarga, dan mediasi tidak mencapai kesepakatan. Kepala suku bertindak sebagai penengah di antara para pihak yang bersengketa.

5. Penyelesaian melalui kepala adat (ondoafi), upaya penyelesaian ini adalah upaya penyelesaian melalui lembaga adat. Kepala adat bertindak sebagai hakim adat yang berwenang untuk memeriksa dan memutus delik adat yang terjadi. Hasil perdamaian yang telah disepakati tersebut selanjutnya para pihak saling bersalaman dan berpelukan di hadapan ondoafi dan dengan demikian maka perselisihan dinyatakan selesai dan tidak ada lagi saling dendam dan bermusuhan, dan kedua belah pihak dinyatakan sebagai satu keluarga/suku. ${ }^{25}$

${ }^{25}$ Budiyanto. (2015). Revitalisasi Peradilan Adat Sebagai Alternatif Penyelesaian Delik Adat Pada Masyarakat Hukum Adat Papua (Disertasi), Makassar: Program Pascasarjana
6. Dalam hal menyelesaikan jenis delik yang dianggap berat, maka masyarakat adat bekerjasama dengan kepolisian untuk menyelesaikannya, sedangkan delik adat yang sifatnya ringan dan menyangkut persoalan adat diselesaikan oleh lembaga adat dan pihak kepolisian hanya diberi pemberitahuan atau sebagai laporan saja dan apabila kasus tanah adat yang disertai ancaman, pukulan/perkelahian dibagi menjadi 2 (dua) masalah yakni tanah adat diselesaikan oleh lembaga adat sedangkan ancaman, pukulan dan perkelahian ditangani oleh pihak kepolisian.

Aparat Kepolisian di Papua sangat dibutuhkan keberadaan dan keterlibatannya dalam membantu masyarakat untuk menyelesaikan delik adat yang terjadi. Menurut Skep Kapolri 737/X/2005 tentang Kebijakan dan Strategi Perpolisian Masyarakat (Jakstra Polmas) bahwa penyelesaian perkaraperkara pidana tertentu di masyarakat dapat ditempuh melalui cara-cara alternatif penyelesaian sengketa di samping adanya diskresi yang dimiliki oleh kepolisian. Petugas Polmas (Babinkamtibmas/Bhabinkamtibmas) yang bertugas pada Kelurahan/ Desa/

Universitas Hasanuddin, hal. 319-326. Lihat. Budiyanto. (2014). Penyelesaian Tindak Pidana (Delik Adat) Melalui Keadilan Restoratif (Restorative Justice). Jurnal Hukum dan Masyarakat Fakultas Hukum Universitas Cenderawasih. Tahun. 13. No. 2. April 2014. ISSN 1693-2889, hal. 48-49 
Kawasan tertentu diberikan kewenangan bersama-sama masyarakat untuk menyelesaikan beberapa perkara pidana dengan tujuan untuk menemukan kedamaian, sehingga tidak memicu terjadinya konflik yang lebih luas lagi. Lebih lanjut lagi dalam Petugas Polmas berdasarkan Skep Kapolri 433/VII/2006 yang merupakan penjabaran dari Jakstra Polmas tadi memberikan panduan kepada Petugas Polmas dalam penyelesaian perkara ringan/pertikaian warga, bahkan juga mengatur panduan khusus menghadapi orang yang bersikap menolak/melawan. Pada tahun 2008 Jakstra Polmas diperkuat lagi melalui Peraturan Kapolri No. 7/2008. Polri terus berusaha menyempurnakan konsepnya tentang Mediasi Penal melalui Surat Kapolri No. Pol.: B/3022/ XII/2009/Sdeops Tgl. 14 Des 2009 tentang Penanganan Kasus melalui Mediasi Penal, yaitu terhadap tindak pidana dengan kerugian kecil dan disepakati oleh para pihak yang berperkara, melalui prinsip musyawarah mufakat dengan melibatkan RT/RW dan diketahui masyarakat, serta menghormati norma hukum sosial/adat dan berazaskan keadilan bagi para pihak.

\section{Bentuk-bentuk Penyelesaian Delik Adat}

Berdasarkan literatur yang diperoleh menunjukkan bahwa penerapan keadilan restoratif (Restorative justice) dalam penyelesaian delik adat, dapat dilihat dalam berbagai putusan pengadilan sebagai berikut:

1. Dalam kasus pencurian bendabenda suci keagamaan di Pura Banjar Tebongkang Desa Singakerta Kecamatan Ubud, Kabupaten Gianyar yang telah diputus Pengadilan Negeri Gianyar dalam putusannya No. 177/Pid.B/2006/ PN.GIR, tanggal 13 November 2006, oleh karena pelaku bukan warga setempat maka warga Banjar Tebongkang melakukan sendiri upaya pemulihan dengan mengadakan upacara mecaru manca sata.

2. Putusan Pengadilan Negeri Denpasar Nomor 104/PN.Dps/ Pid/1980, Putusan Pengadilan Negeri Denpasar Nomor 2/Pid.B/ 1985/PN.Dps, Putusan Pengadilan Negeri Klungkung Nomor 24/ Pid./S/1992/ PN.KLK. dan Putusan Pengadilan Negeri Denpasar Nomor 25/Pid.B/1986/ PN.Dps. Hakikatnya, putusan konteks di atas melanggar ketentuan Delik Adat "Lokika Sanggraha" merupakan delik adat bersifat spesifik dan hanya terdapat di Bali, dan juga dikenakan bagi mereka yang tunduk pada hukum Adat Bali, sehingga dengan demikian, jikalau salah satu fihak saja tunduk kepada hukum adat Bali, maka di sini eksistensi Delik Adat 
Lokika Sanggraha tidak nampak di dalamnya.

3. Pengadilan Negeri Bone dalam putusannya tertanggal 27 Juni 1995 Nomor 17/b/1977 menghukum dua terdakwa persetubuhan sumbangpati (bloedschande, incest) yang disebut malaweng (sapa'ritana) dengan hukuman penjara selama dua tahun kepada masing-masing terdakwa, yaitu terhadap terdakwa lelaki BN, usia 30 tahun, dengan terdakwa, perempuan, S, usia 40 tahun. Lelaki BN berkali-kali menyetubuhi mertua perempuannya $\mathrm{S}$, sehingga dari persetubuhan ini lahir seorang anak, namun meninggal setelah usia beberapa hari. Pengadilan Negeri Bone dalam pertimbangan hukum keputusannya mendasarkan hal perbuatan persetubuhan sumbangpati (bloedschande, incest) kedua terdakwa dari sudut pandang delik hukum adat. Dikatakan bahwa "perbuatan semacam ini adalah perbuatan yang sangat tercela di daerah ini khususnya, di Indonesia pada umumnya." Hukum adat semacam ini tetap hidup dan dipersubur oleh masyarakat. Pelanggaran delik adat ini disebut melaweng. Hakim dalam pertimbangan hukumnya juga mengemukakan bahwa tidak terdapat padanan perbuatan melaweng dalam KUHP Pidana (W.v.S 1918). ${ }^{26}$

26 Dikutip pada Halaman Web: http://putusan.mahkamahagung.go.id/pengadila n/ mahkamah-agung/. Tanggal 15 Mei 2014. Pukul.12.00. Lihat. Lilik Mulyadi, Hukum Dan Putusan Adat Dalam Praktik Peradilan Negara, Disampaikan dalam dialog Nasional dengan tema, "Merumuskan Kedudukan Peradilan Adat Dalam Sistem Peradilan Nasional", di Hotel Royal Kuningan, Jakarta, pada hari: Kamis, 10
4. Putusan No.93/Pid.B/2013/PN. Mal. Pengadilan Negeri Malinau telah menjatuhkan putusan bahwa terdakwa Muhammad Salman Alparisi, secara sah dan meyakinkan bersalah melakukan tindak pidana "pencemaran nama baik" sebagaimana diatur dan diancam pidana dalam dakwaan alternatif kedua melanggar Pasal 310 Ayat (1) KUHP; Tuntutan Jaksa Penuntut Umum, pidana penjara selama 7 (tujuh) bulan dikurangi dengan masa penahanan yang telah dijalani oleh terdakwa dengan perintah terdakwa tetap ditahan; Hal-hal yang memberatkan: Tidak Ada; Hal-hal yang meringankan: Terdakwa belum pernah dihukum; Terdakwa berlaku sopan; Terdakwa menyesal dan berjanji tidak akan mengulangi lagi perbuatannya; Terdakwa merupakan tulang punggung keluarga; Bahwa saksi JHONNY LAING telah memaafkan perbuatan terdakwa; Dipersidangan antara saksi JHONNY LAING dan terdakwa saling berjabat tangan dan berpelukan menandakan perdamaian diantara saksi JHONNY LAING maupun terdakwa; Bahwa telah ada perdamaian secara adat antara saksi JHONNY LAING dengan terdakwa sebagaimana yang tertuang dalam Berita Acara Sidang Adat dan perdamaian antara JHONNY LAING dan SALMAN ALFARISY tertanggal 19 Agustus 2013 yang terlampir dalam berkas perkara. Berdasarkan alasan yang memberatkan

Oktober 2013 yang diselenggarakan oleh Perkumpulan Untuk Pembaharuan Hukum Berbasis Masyarakat dan Ekologis (HuMa) dan Mahkamah Agung RI. hal.7. 
dan meringankan Majelis Hakim Menyatakan Terdakwa MUHAMMAD SALMAN ALPARISI telah terbukti secara sah dan meyakinkan bersalah melakukan tindak pidana "PENISTAAN"; dan Menjatuhkan pidana penjara selama 2 (dua) bulan.

5. Putusan Nomor 29 /PID. B/2006/ PN.MAL Pengadilan Negeri Malinau telah menjatuhkan putusan terdakwa PANUS AMBUNG Als JEMMY Bin IKOF, Tempat lahir Desa Seruyung; Umur/tanggal lahir: 16 Tahun /1989; Jenis kelamin Laki laki; Pekerjaan Pelajar SMP Negeri Malinau Utara; Pendidikan: SMP (masih sekolah); Tuntutan Jaksa Penuntut Umum, Menyatakan TERDAKWA bersalah melakukan tindak pidana karena Kelalaiannya menyebabkan orang lain meninggal dunia sebagaimana diatur dan diancam pidana dalam Pasal 359 KUHPidana dalam surat dakwaan Tunggal. Menjatuhkan pidana terhadap terdakwa berupa pidana penjara selama 10 (sepuluh) bulan dengan masa percobaan selama 2 (dua) tahun; Hal-hal yang memberatkan adalah Perbuatan terdakwa mengakibatkan matinya orang lain; Terdakwa sebagai seorang yang lebih dewasa dari korban seharusnya dapat berbuat lebih hati-hati. Hal-hal yang meringankan Terdakwa belum pernah dihukum dan sopan selama dipersidangan; Terdakwa masih berusia dibawah umur dan pada saat kejadian masih sebagai pelajar yang bersekolah di SMP; Terdakwa dan keluarganya telah memberikan santunan kepada keluarga korban. Putusan Hakim Pengadilan Negeri Malinau, Menyatakan TERDAKWA telah terbukti secara Sah dan menyakinkan bersalah melakukan tindak pidana" KARENA KEALPAANNYA MENYEBABKAN ORANG MATI "; Menjatuhkan pidana terhadap diri terdakwa PANUS AMBUNG Als JEMMY Bin IKOF oleh karena itu dengan pidana penjara selama 8 (delapan) bulan.

6. Putusan Nomor: 41/Pid.B/2012/ PN.BIK. Pengadilan Negeri Biak, menjatuhkan putusan dalam perkara Terdakwa PAULUS IVRAIN MANASE RUMWAROPEN. Hal-hal yang memberatkan: Terdakwa pada waktu mengendarai mobil dalam keadaan dipengaruhi minuman beralkohol; Hal-hal yang meringankan: Terdakwa bersikap sopan dalam persidangan; Terdakwa belum pernah dihukum; Terdakwa menyesal atas perbuatannya dan berjanji tidak akan mengulanginya lagi; Antara keluarga terdakwa dengan keluarga korban telah menyelesaikan masalah ini secara adat sebagaimana tertuang dalam Berita Acara Penyelesaian dan Perdamaian antara Keluarga Paulus Rumaropen dengan Keluarga (Alm) Markus Rumpaidus, tanggal 5 September 2012 Nomor: 464/DBK/2012, yang ditandatangani oleh masing-masing pihak keluarga, dengan pembayaran uang sejumlah Rp. 13.000.000,(tiga belas juta rupiah) dan barang/benda pecah belah berupa piring besar dan piring kecil makan dengan jumlah 132 buah oleh pihak keluarga terdakwa 
yang diserahkan Penyelesaian dan Perdamaian terlampir). Majelis Hakim tidak memungkiri bahwa pertanggung jawaban pidana Terdakwa tidak akan hapus karena adanya pembayaran sejumlah uang dan barang sebagai penyelesaian secara adat kepada pihak keluarga korban, namun adalah bijaksana dengan menjadikan peristiwa tersebut sebagai hal yang meringankan bagi Terdakwa, karena bagi terdakwa telah ditegakkan rasa keadilan yang hidup dalam masyarakat (Social Justice). Berdasarkan pertimbangan tersebut Hakim Pengadilan Biak menjatuhkan putusan: Menyatakan Terdakwa PAULUS IVRAIN MANASE RUMWAROPEN telah terbukti secara sah dan meyakinkan, bersalah melakukan tindak pidana "KARENA KELALAIANNYA MENGAKIBATKAN KECELAKAAN LALU LINTAS YANG MENGAKIBATKAN ORANG LAIN MENINGGAL DUNIA“; Menjatuhkan pidana kepada Terdakwa PAULUS IVRAIN MANASE RUMWAROPEN dengan pidana penjara selama 8 (delapan) bulan dan denda sebesar Rp. Rp. 5.000.000,00 (lima juta rupiah), dengan ketentuan jika pidana denda tidak dibayar diganti dengan pidana kurungan selama 2 (dua) bulan.

Berdasarkan beberapa putusan yang telah dikemukakan tersebut, dapat dikatakan bahwa hakim dalam menjatuhkan putusan terhadap delik adat tetap mengacu pada hukum positif, namun apabila dalam penyelesaian delik adat yang terjadi pihak pelaku dan korban telah menerapkan konsep keadilan restoratif, yang berupa perdamaian, maka penyelesaian secara adat yang telah dilakukan tidak serta merta dapat membebaskan terdakwa dari hukuman pidana. Perdamaian secara adat atau ganti kerugian yang diberikan pelaku kepada korban atau keluarga hanya merupakan dasar pertimbangan hakim yaitu sebagai hal-hal yang meringankan dalam putusan. Dengan kata lain perdamaian yang sudah dilakukan dan santunan yang telah diberikan oleh pelaku kepda korban atau keluarganya hanya untuk meringankan hukuman terdakwa saja, namun dalam kasus tertentu penyelesaian delik adat cukup diselesaikan di tingkat peradilan adat saja dan tidak sampai dilimpahkan ke pengadilan formal.

\section{PENUTUP}

Penyelesaian delik adat di Papua dilakukan dengan menerapkan konsep keadilan restoratif, yaitu ide penyelesaiannya dilakukan oleh pelaku kepada korban atau keluarga korban, apabila tidak berhasil akan diselesaikan melalui keluarga pelaku dan keluarga korban, atau melalui kepala suku/Ondoafi, atau 
melalui peradilan adat. Konsep keadilan restoratif ini diterapkan dalam penyelesaian delik adat semata-mata sebagai upaya untuk memulihkan penderitaan yang dialami korban dan untuk memperbaiki keseimbangan kosmis yang terganggu dalam masyarakat.

Bentuk-bentuk penyelesaian delik adat ditempuh melalui beberapa cara yaitu diselesaikan oleh para pihak sendiri (antara pelaku dan korban), melalui keluarga masing-masing pihak (antara keluarga pelaku dan keluarga korban), diselesaiaikan oleh kepala suku/ondoafi (diselesaikan melalui lembaga peradilan adat). Penyelesaian secara adat tetap menjadi primadona masyarakat adat di Papua untuk menyelesaikan delik adat yang terjadi antar masyarakat hukum adat. Penyelesaian delik adat yang dilakukan para pihak dapat dijadikan sebagai dasar pertimbangan hakim untuk meringankan hukuman yang akan dijatuhkan kepada pelaku, apabila kasusnya ditangani oleh peradilan formal.

\section{DAFTAR PUSTAKA}

Abintoro Prakoso. (2013). Pembaruan Sistem Peradilan Pidana Anak. Yogyakarta: Laksbang Grafika.
Bambang Waluyo. (2015). Relevansi Doktrin Restorative Justice Dalam SIstem Pemidanaan di Indonesia (The Relevance of the Doctrine on Restorative Justice in the Indonesian Sentencing System), Hassanuddin Law Review, Volume 1, Issu 2, August 2015.

Budiyanto. (2015). Revitalisasi Peradilan Adat Sebagai Alternatif Penyelesaian Delik Adat Pada Masyarakat Hukum Adat Papua (Disertasi). Makassar: Program Pascasarjana Universitas Hasanuddin.

Budiyanto. (2014). Penyelesaian Tindak Pidana (Delik Adat) Melalui Keadilan Restoratif (Restorative Justice). Jurnal Hukum dan Masyarakat Fakultas Hukum Universitas Cenderawasih. Thn.13.No.2. April 2014

Edwin Syah Putra. Restorative Justice (Pengertian, Prinsip dan Keberlakuannya Dalam Sistem Hukum Pidana Indonesia). Dikutip pada laman web: http://edwinnotaris. blogspot.com/2013/09/restorative -justice-pengertian-prinsip.html.

Tanggal 20 September 2013. Pukul. 17.50. 
George Ritzer dan Douglas J. Munawara, M. Syukri Akkub, Goodman. (2003). Teori Sosiologi Musakkir. (tanpa tahun). Modern. Jakarta: Kencana.

Hadi Supeno. (2010). Kriminalisasi Anak Tawaran Gagasan Radikal Peradilan Anak Tanpa Pemidanaan. Jakarta: PT. Gramedia Pustaka Utama.

Hendra Nurtjahjo dan Fokky Fuad. (2010). Legal Standing Kesatuan Masyarakat Hukum Adat Dalam Berperkara di Mahkamah Konstitusi. Jakarta: Salemba Humanika.

Hilman Hadikusuma. (1989). Hukum Pidana Adat. Bandung: Alumni. Ismael Roby Silak. (2011). Konflik Perang dan Perdamaian Orang Yali di Angguruk. Makassar: Pustaka Refleksi.

I Made Widnyana. (1993). Kapita Selekta Hukum Pidana Adat. Bandung: PT. Eresco.

Kuat Puji Prayitno. (2012). Restorative Justice Untuk Peradilan Di Indonesia (Perspektif Yuridis Filosofis Dalam Penegakan Hukum In Concreto). Jurnal Dinamika Hukum Vol.12 No.3 September 2012. Fakultas Hukum Universitas Jenderal Soedirman. Pendekatan Restorative Justice Dalam Penyelesaian Tindak Pidana Yang Dilakukan Oleh Anak Di Kota Makassar. Makassar: Fakultas hukum Universitas Hasanuddin.

Nyoman Serikat Putra Jaya. (2005). Relevansi Hukum Pidana Adat Dalam Pembaharuan $\mathrm{Hu}$ kum Pidana Nasional. Bandung: PT Citra Aditya Bakti.

Peter Mahmud Marzuki. (2008). Penelitian Hukum. Jakarta: Kencana Prenada Media Group. Rufinus Hotmaulana Hutauruk. (2013). Penanggulangan Kejahatan Korporasi Melalui Pendekatan Restoratif Suatu Terobosan Hukum. Jakarta: Sinar Grafika.

Soerjono Soekanto dan Mustafa Abdullah. (1982). Pengantar Hukum Adat Indonesia. Jakarta: PT RajaGrafindo Persada.

Tolib Setiady. (2008). Intisari Hukum Adat Indonesia (Dalam Kajian Kepustakaan). Bandung:Alfabeta. T.O Ihromi. (2001). Antropologi Hukum Sebuah Bunga Rampai. Jakarta: Yayasan Obor Indonesia. 